University of Nebraska - Lincoln

DigitalCommons@University of Nebraska - Lincoln

\title{
The Collection, Rearing, and Release of Parasites of the European Corn Borer in 1942
}

Charles A. Clark

USDA-ARS

Stanley W. Carter

USDA-ARS

Follow this and additional works at: https://digitalcommons.unl.edu/usdaarsfacpub

Clark, Charles A. and Carter, Stanley W., "The Collection, Rearing, and Release of Parasites of the European Corn Borer in 1942" (1943). Publications from USDA-ARS / UNL Faculty. 1552.

https://digitalcommons.unl.edu/usdaarsfacpub/1552

This Article is brought to you for free and open access by the U.S. Department of Agriculture: Agricultural Research Service, Lincoln, Nebraska at DigitalCommons@University of Nebraska - Lincoln. It has been accepted for inclusion in Publications from USDA-ARS / UNL Faculty by an authorized administrator of DigitalCommons@University of Nebraska - Lincoln. 
the previous year. Approximately 15,000 adult parasites were reared, of which approximately 75 per cent were adults of the polyembryonic $M$. gifuensis from borers collected in southeastern Massachusetts.

Table 1.-Releases of European corn borer parasites during 1942.

\begin{tabular}{|c|c|c|c|c|}
\hline \multicolumn{2}{|c|}{ Reuease Locality } & \multirow[b]{2}{*}{$\begin{array}{c}\text { DATE } \\
\text { OF } \\
\text { RELEASE }\end{array}$} & \multicolumn{2}{|c|}{ Parasites Releagen } \\
\hline $\begin{array}{l}\text { State and } \\
\text { County }\end{array}$ & Township & & $\begin{array}{c}\text { Inareo- } \\
\text { Lata } \\
\text { punctoria }\end{array}$ & $\begin{array}{l}\text { Macro- } \\
\text { contrus } \\
\text { gifucnsis }\end{array}$ \\
\hline & & & Number & Number \\
\hline $\begin{array}{l}\text { Ilinois: } \\
\text { Vermilion } \\
\text { Indiuna: }\end{array}$ & Grant & July 4 & 594 & 1,895 \\
\hline Tipton & Wildcat & June 80 & 595 & 1,065 \\
\hline Burlington & Burlington & $\begin{array}{lr}\text { July } & 6 \\
\text { Aug. } & 8 \\
\text { Aug. } 11\end{array}$ & $\begin{array}{l}148 \\
165 \\
-\end{array}$ & $\begin{array}{l}1.019 \\
2,244\end{array}$ \\
\hline $\begin{array}{l}\text { Pennsylvania: } \\
\text { Montgomery }\end{array}$ & Skippack & June 28 & 590 & 2,068 \\
\hline $\begin{array}{l}\text { Wisconsini } \\
\text { Sheboygan }\end{array}$ & Vilson & July 4 & 600 & 1,949 \\
\hline $\begin{array}{l}\text { Total } \\
\text { Grand total1 }\end{array}$ & 14,623 & . & 2,602 & 11,140 \\
\hline
\end{tabular}

\section{The Collection, Rearing, and Release of Parasites of the European Corn Borer in $1942^{1}$}

\section{Charles A. Clark and Stanley W. Carter U.S.D.A., Agr. Res. Adm., Bureau of Entomology and Plant Quarantine}

To furnish parasites for release in 1942, overwintering corn borer larvae were collected in two localities, central Connecticut and southeastern Massachusetts, in the fall of 1941 . Several of the most important parasites of the European corn borer imported from Europe and the Orient are established and abundant in these localities.

Collections were made in central Connecticut during the period October 27 to November 15, 1941. A total of 14,214 host larvae, or an average of 861 per working day, were obtained. Collections in southeastern Massachusetts were made during the period November 12 to 25 but, owing to a very light plant infestation, only 368 larvae were obtained per working day. The 3735 larvae from southeastern Massachusetts brought the total number of host larvae available to 17,949 . These larvae were placed in collecting cans in the field and shipped by railway express to the Moorestown, N. J., corn borer laborntory, where they were placed in cold storage for the winter at $35^{\circ} \mathrm{F}$, and approximately 70 per cent relative bumidity. The larvae were given contact water at monthly intervals. In the spring of 1942 they were isolated individually in 1-inch glass vials. In order to have adult parasites available at the right time for release where needed, the material was held in cold storage until June 1, when it was removed and placed in an incubator room. The temperature was gradually raised to $80^{\circ}$ and the relative humidity was maintained at approximately 70 per cent.

Four exotic species of parasites.-Macrocentrus gifuensis Ashm., Inareolata punctoria Roman, Lydella grisescens $\mathbf{R}$. and D., and Chelonus annulipes Wesm. were reared from the host material collected

1 For releases prior to 1942 see Insect Pest Survey Bul., v. 21 , Suppl. to No. 8, Oct. 15, 1941 .
${ }_{1}^{1}$ Including 48 Chelonus annulipes relensed at Burlington, N. J. on June 24 and 749 Lydella grisescens released at Sheboygan, Wisconsin, on June 25.

Parasite releases were made in the five states, Illinois, Indiana, New Jersey, Pennsylvania, and Wisconsin. Brcause of the small numbers available, the egg-larval parasite Chelonus annulipes was released only in New Jersey and the tachinid Lydella grisescens only in Wisconsin. The ichneumonid $I n$ areolata punctoria and the braconid Macrocentrus gifuensis were released in all five of the states listed.

All releases, with the possible exception of those made in Wisconsin, were accomplished at a time and under host-infestation conditions to afford the parasites a favorable opportunity of becoming well established.

The releases of corn borer parasites liberated during the 1942 season are listed in table1.-2-10-43. 